\title{
Schistosomiasis and Urothelial Bladder Carcinoma
}

\author{
Rodrigo de Carvalho Holanda Leite1, Cecília Maria de Carvalho Xavier Holanda², \\ Paulo José de Medeiros ${ }^{3,4}$ \\ ${ }^{1}$ Onofre Lopes University Hospital (HUOL), Natal, Brazil \\ ${ }^{2}$ Department of Microbiology and Parasitology, Federal University of Rio Grande do Norte (UFRN), Natal, Brazil \\ ${ }^{3}$ Department of Integrated Medicine, Onofre Lopes University Hospital (HUOL), Natal, Brazil \\ ${ }^{4}$ Department of Integrated Medicine, Federal University of Rio Grande do Norte (UFRN), Natal, Brazil \\ Email: cechol@ufrnet.br
}

Received 5 July 2014; revised 4 August 2014; accepted 3 September 2014

Copyright (C) 2014 by authors and Scientific Research Publishing Inc.

This work is licensed under the Creative Commons Attribution International License (CC BY). http://creativecommons.org/licenses/by/4.0/

(c) (i) Open Access

\begin{abstract}
Bladder cancer is the most common malignancy of the urinary tract and it affects four times more men than women. The relationship between bladder tumors and Schistosoma haematobium is well known, but only sporadic cases of bladder infection due to Schistosoma mansoni have been reported. Schistosoma mansoni infection causes an endemic disease in Brazil (schistosomiasis) and gastrointestinal disorders are very common, but disease of the urinary tract is atypical. The aim of this study was to describe a case of a patient presenting schistosomiasis ( $S$. mansoni) and urothelial bladder carcinoma. In this case, a 37-year-old man with intermittent painless gross hematuria was investigated. Cystoscopy revealed a small pedunculated lesion in the bladder dome. Transurethral resection revealed urothelial carcinoma of the bladder, low degree, unrepresentative of the muscular layer of the bladder. After 30 days, a new transurethral resection was performed to sample acquisition of the muscular layer on the basis of the scar. Histopathology was negative for malignancy (Tumor Node Metastasis: TNM-T1). During this procedure, there was evidence of dark rounded lesion in the bladder dome. It was excised and the histopathology showed viable eggs of Schistosoma mansoni. The patient was treated orally with oxamniquine and remained in oncological monitoring with cystoscopy quarterly and serial clinical evaluation. This case reveals a rare finding of Schistosoma mansoni in the bladder and urothelial bladder carcinoma coexisting in the same patient.
\end{abstract}

\section{Keywords}

Schistosoma mansoni, Bladder Cancer, Schistosomiasis, Oxamniquine 


\section{Introduction}

Bladder cancer is the most common malignancy of the urinary tract, with a mortality rate of 4 per 100,000 worldwide among men, and 1.1 per 100,000 among women. It affects four times more men than women. $75 \%$ 85\% of patients with bladder cancer present with disease confined to the mucosa or submucosa [1]. Known risk factors are occupational exposure to aromatic amines and smoking. Cigarette smoking is now recognized as a major cause of bladder cancer in developed countries and it is responsible for tripling the risk of developing cancer and increases the mortality rate of the disease [1] [2]. The most common clinical finding of this disease is the macroscopic hematuria [2].

Several biological factors such as bacterial infections and immunological status are implicated in predisposing individuals to bladder cancer [3] [4] and there are several well-documented relationships between infections with certain parasites and the development of cancer, in particular schistosomiasis and bladder cancer [5] [6]. It is well known that the relationship between squamous cell carcinoma and bladder infection by Schistosoma haematobium occurs mainly among women. In turn, the relationship between urothelial carcinoma and Schistosoma haematobium infection is not clear [7].

Schistosomiasis is a fairly prevalent communicable disease in tropics and subtropics caused by a trematode of the genus Schistosoma. Human schistosomiasis is generally caused by three major species: Schistosoma mansoni, distributed throughout Africa, South America (including Brazil, Suriname, Venezuela) and Caribbean (risk is low); Schistosoma japonicum, found in Indonesia and parts of China and Southeast Asia; and Schistosoma haematobium, distributed throughout Africa and found in areas of the Middle East [8]. It affects more than 200 million people worldwide, with over 700 million living under conditions favouring transmission [8].

Schistosoma mansoni infection causes an endemic disease in Brazil (schistosomiasis) and gastrointestinal disorders are very common, but disease in the urinary tract is atypical [9].

In literature there are only sporadic cases of bladder infection by Schistosoma mansoni reported without coexisting with bladder carcinoma [1].

The aim of this study was to describe the case of a patient presenting a low-grade urothelial bladder carcinoma coexisting with bladder schistosomiasis (S. mansoni).

\section{Case Report}

A 37-year-old male patient originating from an endemic area for schistosomiasis in Brazil (Natal-RN) was seen at our hospital because of sporadic painless gross hematuria (four episodes in two years). He denied smoking, drinking and working as a painter or similar activity. Physical examination revealed negative abdominal findings and laboratory studies disclosed the following values: white blood cell count 5200/mm ${ }^{3}$ with neutrocyte/

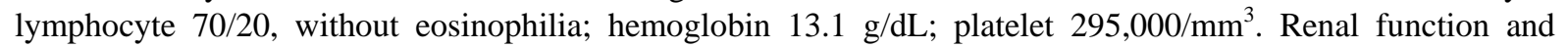
electrolytes were within normal limits. Three consecutive stool tests were negative for S. mansoni ova and carcinoembryonic antigen (CEA) level was $4.27 \mathrm{ng} / \mathrm{mL}$ (normal range $<5 \mathrm{ng} / \mathrm{mL}$ ). Cystoscopy revealed a small pedunculated lesion in the bladder dome of diameter $0.5 \mathrm{~cm}$, which was resected. Transurethral resection revealed urothelial carcinoma of the bladder, low degree, unrepresentative of the muscular layer of the bladder. The patient was discharged after 3 days. After 30 days, a new transurethral resection was performed to sample acquisition of the muscular layer on the basis of the scar. During this procedure, there was evidenced a dark rounded lesion in the bladder dome (non-existent in the previous procedure), that was resected. It was also resected the basis of the scar to the muscular layer representation. Histopathology of the muscular layer was negative for malignancy (Tumor Node Metastasis: TNM-T1). Histopathology of the bladder dome lesion showed a chronic granulomatous inflammatory process with Schistosoma mansoni viable eggs (Figure 1 and Figure 2). The patient was treated orally with oxamniquine and remained in oncological monitoring with cystoscopy quarterly and serial clinical evaluation, without recurrence of disease until nowadays. This case reveals a rare finding of Schistosoma mansoni in the bladder and urothelial bladder carcinoma coexisting in the same patient.

\section{Discussion}

In endemic areas, schistosomal infection has been implicated in the etiology of several human malignancies including bladder, liver, and colorectal cancer [9]. Bladder cancer is the most common malignancy involving the 


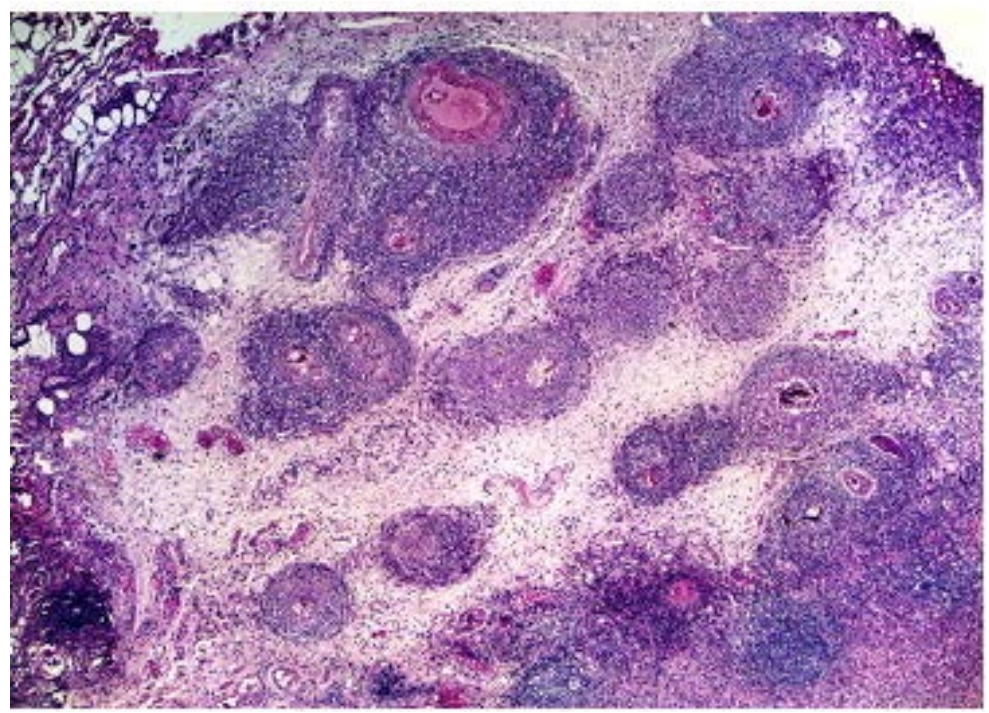

Figure 1. Histological section showing multiple granulomas (HE 40×).

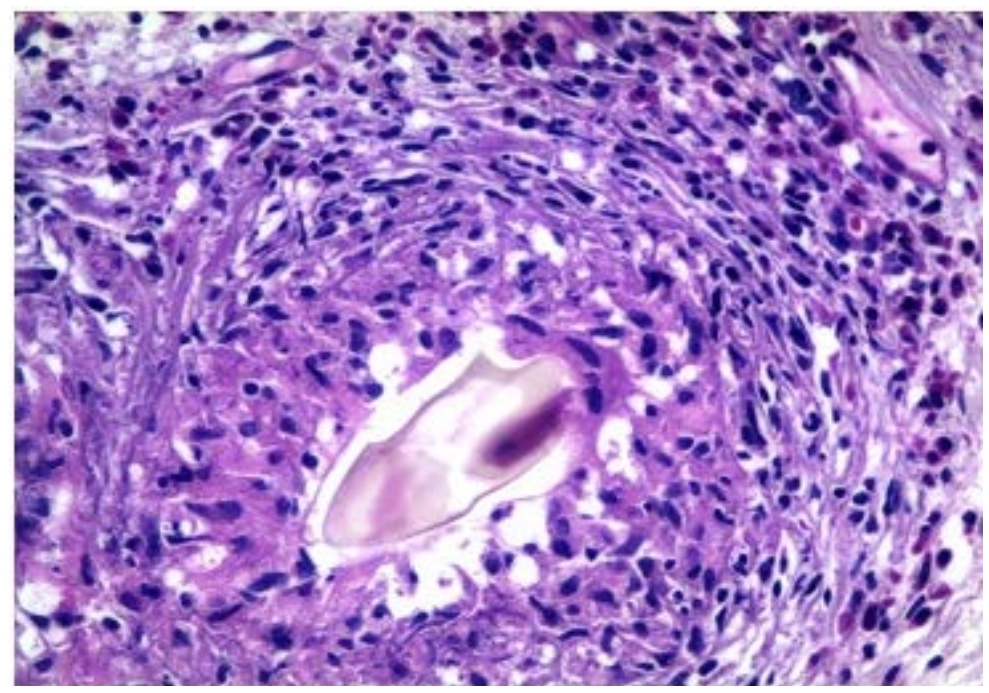

Figure 2. Typical granulomatous lesion of S. mansoni egg and its lateral spike (HE 40×).

urinary system and it can be the most expensive malignancy on a per-person basis given the cost of multiple surgeries and the frequency of follow-up [1].

Urothelial (transitional cell) carcinoma is the predominant histologic type in the United States and Europe, where it accounts for 90 percent of all bladder cancers. In other areas of the world, non-urothelial carcinomas are more frequent [1]. Approximately $30 \%$ of patients present with muscle invasive urothelial carcinoma of the bladder [1] and 5\% have metastatic disease at presentation. Radical cystectomy is the usual treatment of choice for muscle-invasive bladder cancer in the United States, although bladder sparing approaches have gained ground in recent years [1].

It has been reported recently that schistosome-induced chronic inflammation and irritation in the urinary bladder are associated with increased cancer initiation at the site of inflammation [10]. Inflammatory cells such as macrophages and neutrophils are important sources of endogenous oxygen radicals, which are also implicated in the formation of carcinogenic N-nitrosamines [11]. Inflammatory cells also participate in the activation of procarcinogens, such as aromatic amines and polycyclic aromatic hydrocarbons [12]. Since the aromatic amines are an important group of bladder carcinogens, an increased number of inflammatory cells in the urinary bladder 
of schistosomal patients may enhance the carcinogenic potential of these agents by increasing their rate of activation. Studies on mice clearly demonstrated that $S$. mansoni infection increased the activity of drugmetabolizing enzymes including P-450, cytochrome $b_{5}$, and NADPH-cytochrome c reductase at earlier stages (30 days) of schistosomal infection [13].

The case reported here shows a rare form of ectopic schistosomiasis. Only four other cases of bladder involvement were reported around the world, all of them in Brazil [14]. In 1944, a study by necropsy performed by Meira [15] showed the first case in Brazil. In 1977 Sayão and colleagues [16] described the case of a 37-yearold man affected with this rare bladder form of the disease, who was treated only with oral medications. Mitre et al. [17] in 1980 described another case of a 23-year-old man with dysuria and terminal hematuria who was treated with oxamniquine in association with transurethral resection of the lesions. Lopes and colleagues [14] in 2006 reported the case of a 36-year-old man whose treatment was also transurethral resection in association with oxamniquine. In our case, transurethral resection biopsy was of great importance in diagnosis, due to a suspected bladder cancer.

\section{Conclusion}

This case reveals a rare finding of a chronic granulomatous inflammatory process caused by viable eggs of Schistosoma mansoni in the bladder coexisting with urothelial bladder carcinoma in the same patient, increasing the curiosity of the possible causal relationship between them.

\section{Conflict of Interest}

None declared.

\section{References}

[1] Jamal, A., Bray, F., Center, M.M., Ferlay, J., Ward, E. and Forman, D. (2011) Global Cancer Statistics. Cancer Journal for Clinicians, 61, 69-90. http://dx.doi.org/10.3322/caac.20107

[2] Jankovic, S. and Radosavljevic, V. (2007) Risk Factors for Bladder Cancer. Tumors, 93, 4-12.

[3] Wilkins, H.A. (1977) Schistosoma haematobium in a Gambian Community-The Prevalence of Bacteriuria and Hypertension. Annals of Tropical Medicine and Parasitology, 71, 179-186.

[4] Badawi, A.F. and Mostafa M.H. (1993) Possible Mechanisms of Alteration in the Capacities of Carcinogen Metabolising Enzymes during Schistosomiasis and Their Role in Bladder Cancer Induction. Journal of International Medical Research, 21, 281-305.

[5] Lopes, E.J.A., de Almeida, C.E.R. and Jacobino, M. (2007) Schistosomiasis Mansoni in the Seminal Vesicle. Revista da Sociedade Brasileira de Medicina Tropical, 40, 341-342. http://dx.doi.org/10.1590/S0037-86822007000300018

[6] Tamimi, Y., Bringuier, P.P., Smit, F., Bokhoven, A., Abbas, A., Debruyne, F.M. and Schalken, J.A. (1996) Homozygous Deletions of $16^{\mathrm{INK} 4}$ Occur Frequency in Bilharziasis-Associated Bladder Cancer. International Journal of Cancer, 68, 183-187. http://dx.doi.org/10.1002/(SICI)1097-0215(19961009)68:2<183::AID-IJC7>3.0.CO;2-U

[7] Pelucchi, C., Bosetti, C., Negri, E., Malvezzi, M. and La, V.C. (2006) Mechanisms of Disease-The Epidemiology of Bladder Cancer. Nature Clinical Practice Urology, 3, 327-340. http://dx.doi.org/10.1038/ncpuro0510

[8] Gryseels, B., Polman, K., Clerinx, J. and Kestens, L. (2006) Human Schistosomiasis. Lancet, 368, 1106-1118. http://dx.doi.org/10.1016/S0140-6736(06)69440-3

[9] Yosry, A. (2006) Schistosomiasis and Neoplasia. Contributions to Microbiology, 13, 81-100. http://dx.doi.org/10.1159/000092967

[10] Rosin, M.P., Anwar, W.A. and Ward, A.J. (1994) Inflammation, Chromosomal Instability and Cancer-The Schistosomiasis Model. Cancer Research, 54, 1929-1933.

[11] Margison, G.P. and O’Connor, P.J. (1990) Biological Consequences of Reactions with DNA. Role of Specific Lesions. Carcinogenesis and Mutagenesis. In: Grover, P.L. and Cooper, C.S., Eds., Handbook of Experimental Pharmacology, Heidelberg K.G., Springer-Verlag, Germany, Vol. 94, 547-571.

[12] Nurse, P. (1997) Regulation of the Eukaryotic Cell Cycle. European Journal of Cancer, 33, 1002-1004. http://dx.doi.org/10.1016/S0959-8049(97)00091-9

[13] Sherif, M., El-Bolkany, N. and Badawi, A. (1975) Clinical Staging of Malignant Lymphoma in Patients Suspected to Have Hepato-Splenic Schistosomiasis. Journal of Tropical Medicine Hygiene, 78, 67-70. 
[14] Lopes, E.J., Santos, T.C. and Martins, V. (2006) Esquistossomose Mansônica Simulando Neoplasia da Bexiga. Revista da Sociedade Brasileira de Medicina Tropical, 39, 287-288. http://dx.doi.org/10.1590/S0037-86822006000300013

[15] Meira, J.A. (1944) Esquistossomose Mansônica com Localização Vesical. Seara Médica, 3, 61.

[16] Sayão, R.H., Cury, J., Carneiro-Neto, J. and Sayão, M.H. (1977) Esquistossomose Mansônica Vesical. Journal of the Brazilian Society of Urology, 3, 114-116.

[17] Mitre, A., Alfer Jr., W., Nahas, W. and Arap, S. (1980) Esquistossomose Mansônica Vesical Simulando TumorRelato de Um Caso. Revista da Associação Médica Brasileira, 26, 74-76. 
Scientific Research Publishing (SCIRP) is one of the largest Open Access journal publishers. It is currently publishing more than 200 open access, online, peer-reviewed journals covering a wide range of academic disciplines. SCIRP serves the worldwide academic communities and contributes to the progress and application of science with its publication.

Other selected journals from SCIRP are listed as below. Submit your manuscript to us via either submit@scirp.org or Online Submission Portal.
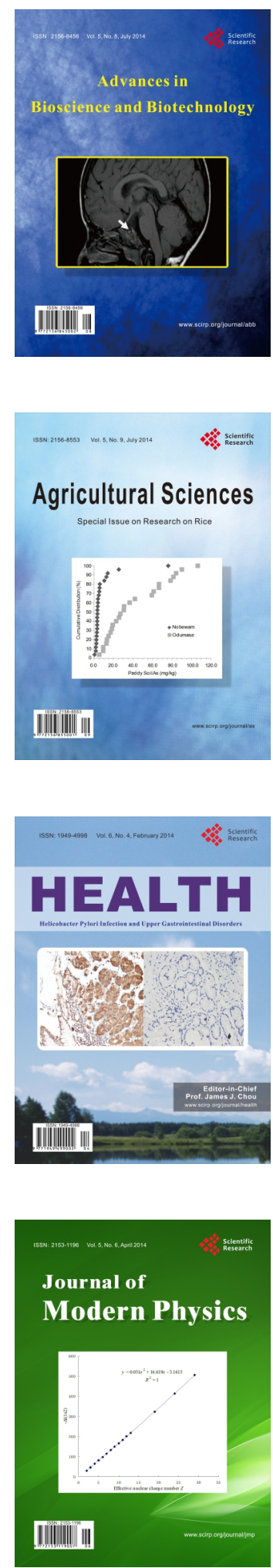
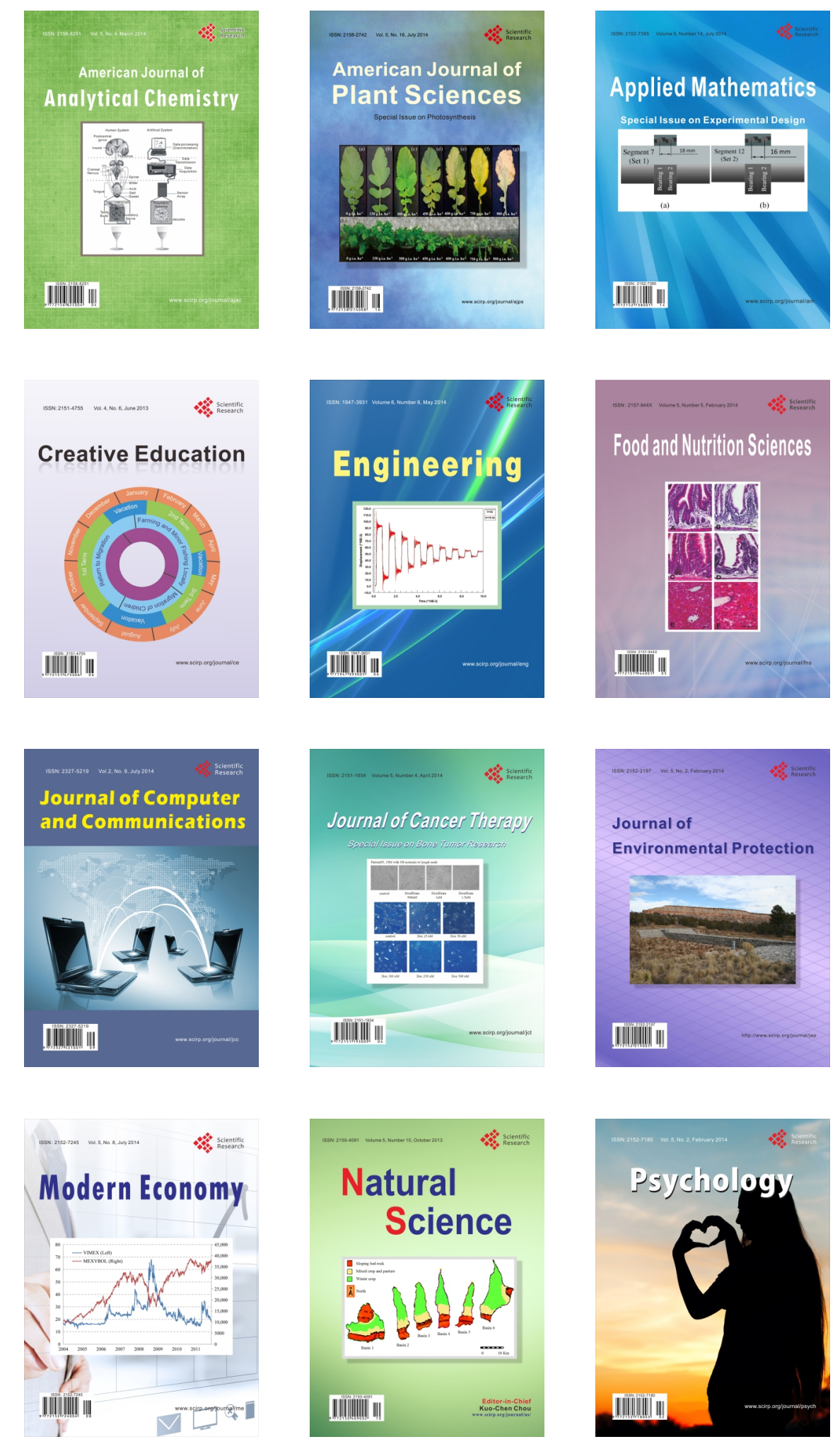